http://dx.doi.org/10.18778/1643-0700.16.13

\title{
India PECYNA*
}

\section{MAGISTRALA WEGLOWA W REGIONIE SZADKOWSKIM}

Streszczenie. Budowa magistrali węglowej była jedną z najważniejszych inwestycji okresu międzywojennego. Połączyła ona Górny Śląsk z Morzem Bałtyckim, z nowo wybudowanym portem w Gdyni, dając nowe możliwości dla eksportu polskiego węgla. Od tamtej pory, linia ta pozostaje jedną z ważniejszych w kraju. Została zaprojektowana głównie z myślą o transporcie towarowym, ale obsługiwała także połączenia pasażerskie. Magistrala węglowa przebiega przez centrum kraju, w tym gminę Szadek i jej okolice. Artykuł opisuje zmiany, jakie pociągnęła za sobą dla regionu szadkowskiego budowa tej linii, oraz wskazuje, jakie jest jej obecne znacznie.

Słowa kluczowe: magistrala węglowa, region szadkowski, małe stacje kolejowe, osiedle kolejarskie.

Przebiegająca przez region szadkowski magistrala węglowa była jedną z największych inwestycji gospodarczych w Polsce w okresie międzywojennym. Jej budowa odegrała niebagatelną rolę zarówno w historii kraju, jak i dla rozwoju wybranych ośrodków.

Funkcjonowanie linii kolejowej na danym terenie jest jednym z ważnych czynników rozwoju społeczno-gospodarczego. W artykule ukazane zostało, w jaki sposób budowa magistrali węglowej wpłynęła niegdyś na zagospodarowanie przestrzeni i rozwój regionu szadkowskiego, a także jaką rolę pełni ona obecnie.

$\mathrm{Na}$ potrzeby artykułu wyznaczono zasięg regionu szadkowskiego (ryc. 1 i 2). Jako punkt wyjścia przyjęto zasięg powiatu szadkowskiego z 1816 r., czyli okresu, kiedy waga Szadku jeszcze znajdowała odzwierciedlenie w podziale administracyjnym (Szadek nie pełnił funkcji administracyjnych wyższego szczebla od 1867 r.), mimo że Szadek zmierzał już ku roli ośrodka o wyłącznie lokalnym znaczeniu ${ }^{1}$. Ze względu na usytuowanie niemal całego odcinka magistrali Otok - Poddębice $\mathrm{w}$ dawnych granicach powiatu szadkowskiego, do regionu szadkowskiego

* India Pecyna, mgr, doktorantka w Katedrze Zagospodarowania Środowiska i Polityki Przestrzennej, Wydział Nauk Geograficznych Uniwersytetu Łódzkiego; e-mail: kurczynska@tlen.pl

1 T. Marszał, Szadek. Monografia miasta, Szadek 1995, s. 20-37. 
zaliczono także stację Poddębice i gminę Poddębice, historycznie należącą do powiatu łęczyckiego. Badaniami objęte zostały gminy, przez które przebiega magistrala węglowa w wyznaczonym regionie: Szadek, Zduńska Wola - gmina wiejska i miasto (powiat zduńskowolski), Sędziejowice (powiat łaski), Zadzim oraz Poddębice (powiat poddębicki). Informacje i dane zebrane na potrzeby artykułu pochodzą z literatury, źródeł internetowych, zasobów PKP oraz inwentaryzacji w terenie.

\section{BUDOWA MAGISTRALI WĘGLOWEJ}

Budowa linii kolejowej łączącej Śląsk z Portami podporządkowana była czynnikom gospodarczym oraz politycznym. Po I wojnie światowej dla polskiej gospodarki kluczowy był eksport węgla i koksu. Wiązał się on z trudnościami, gdyż węzły kolejowe łączące Śląsk i Zagłębie Dąbrowskie z odbiorcami węgla zlokalizowane były na terenie Niemiec i Czechosłowacji. Niemcy, na mocy umów międzynarodowych, do 1925 r. byli zobligowani do przyjmowania polskiego węgla. Wraz z wygaśnięciem obowiązku rozpoczęła się polsko-niemiecka „wojna celna”. Niemcy nałożyli na polskie artykuły górniczo-hutnicze wysokie cła, a nawet zakazali przywozu wybranych z nich. Polska nie pozostała dłużna i ustaliła zakaz importu dla niektórych produktów niemieckich. Działania te doprowadziły do ograniczenia transportu węgla przez Bytom, Kluczbork, Gdańsk, Malbork i Prabuty².

Szczęśliwie dla Polski, w Anglii w 1926 r. wybuchł strajk górników. Brak dostępu do węgla angielskiego skłonił jego odbiorców, głównie kraje skandynawskie, do zakupu węgla z Polski. Niestety pozyskanie kontrahenta nie pozwoliło rozwiązać wszystkich problemów. Eksport węgla na północ wiązał się z koniecznością dostarczenia artykułów do nowo powstającego portu w Gdyni, do którego ze Śląska prowadziły tylko dwie drogi kolejowe. Pierwsza, licząca 666 km, czyli zdecydowanie za długa, przebiegała przez Częstochowę, Koluszki, Skierniewice, Kutno, Torun, Bydgoszcz, Tczew i Gdańsk. Druga, prowadząca przez tzw. korytarz kluczborski (terytorium Niemiec) wymagała uregulowania wysokich opłat ${ }^{3}$. Stało się oczywiste, że konieczna będzie budowa nowej linii kolejowej, przebiegającej wyłącznie przez terytorium Polski i łączącej Śląsk z portami jak najkrótszą trasą.

Pierwsze ważne decyzje zapadły w 1925 r. jeszcze przed wygaśnięciem umów z Niemcami. Zdecydowano wtedy o budowie dwóch pierwszorzędnych, normalnotorowych linii: Kalety - Podzamcze, przez Herby i Wieluń oraz Bydgoszcz - Gdynia, przez Maksymilianowo. Pierwszą linię, liczącą $122 \mathrm{~km}$ długości, oddano do użytku w 1926 r., drugą natomiast, o długości 190 km, w 1930 r. Ich budowa pozwoliła zrezygnować z przewozów najbardziej newralgicznymi odcinkami. 17 lutego 1928 r.,

2 J. Śmiałowski, Zakład Taboru Polskich Kolei Państwowych w Zduńskiej Woli - Karsznicach (1933-1993), Zduńska Wola 1993, ZP POLGRAF, s. 9.

3 P. Michalski, Czarna magistrala, „Świat Kolei” 2002, nr 2, s. 10. 
prezydent Rzeczpospolitej, Ignacy Mościcki, wydał zarządzenie upoważniające rząd do budowy pierwszorzędnej, normalnotorowej linii kolejowej użytku publicznego, łączącej Herby ze stacją w Inowrocławiu, z wykorzystaniem odcinków ww. dwóch linii. Trasa linii ustalona została jako: Katowice - Hajduki Wielkie (Chorzów Batory) - Tarnowskie Góry - Kalety - Herby Nowe - Karsznice - Zduńska Wola - Barłogi - Inowrocław - Nowa Wieś - Kapuścisko (Bydgoszcz Wschód) - Maksymilianowo - Szlachta - Kościerzyna - Gdynia. Odcinek Herby Nowe - Karsznice - Zduńska Wola zaczęto realizować niezwłocznie po decyzji prezydenta, zaś odcinek Zduńska Wola - Nowa Wieś dopiero w 1929 r. Na odcinku Kozuby - Zduńska Wola przetarg na budowę torowiska i budowli wygrała firma z Poznania: TRI - Towarzystwo Robót Inżynieryjnych. Realizacja ww. odcinka dawała w 1929 r. w sezonie robót zatrudnienie ok. 330 robotnikom dziennie. Wielu z nich było mieszkańcami regionu szadkowskiego, a część pochodziła z terenów odległych, głównie wschodnich ${ }^{4}$.

Mimo niepełnego zakończenia prac, odcinek Herby Nowe - Zduńska Wola oddano do użytku 8 XI 1930 r., a dzień później odcinek Bydgoszcz - Gdynia. Ich otwarcie było wydarzeniem hucznie świętowanym w skali kraju, uświetnionym przez reprezentacje rządu, z ministrem komunikacji, Alfonsem Kühnem na czele. Problematyczna okazała się być realizacja środkowego odcinka magistrali: Karsznice - Inowrocław. Państwo polskie nie było w stanie podołać finansowo inwestycji, a na problemy wewnętrzne rzucił cień trwający wielki kryzys (1929$1933)^{5}$. Rząd, zmuszony szukać pomocy z zewnątrz, w 1931 r. udzielił koncesji na budowę linii Francusko-Polskiemu Towarzystwu Kolejowemu (FPTK). Jednak kryzys dotknął także firmy francuskie, co uniemożliwiło FPTK dokończenie prac w ciągu trzech lat. Ponownie nie zważając na niepełne wykonanie prac, 1 marca 1933 r. oddano do użytkowania ostatni odcinek magistrali Karsznice - Inowrocław, a całą linię uruchomiono 1 sierpnia $1935 \mathrm{r}^{6}$ Definitywne zakończenie prac na ww. odcinku miało miejsce dopiero wiosną 1938 r., gdy do eksploatacji oddano drugi tor na odcinku Siemkowice - Karsznice. W kwestiach organizacyjnych w 1936 r. wyodrębniona została, podlegająca FPTK, Dyrekcja Kolei Herby Nowe - Gdynia z siedzibą w Bydgoszczy. Ponieważ FPTK nie wywiązało się z w terminie z warunków koncesji, do 1937 r. linia zarządzana była przez dyrekcję polską. Zarząd FPTK rozpoczął się dopiero w 1938 r. ${ }^{7}$ W 1947 r. magistrala poddana została nacjonalizacji i przeszła $\mathrm{w}$ ręce $\mathrm{PKP}^{8}$.

„Węglówka” zelektryfikowana została w latach 1965-1969, natomiast odcinek w regionie szadkowskim w latach 1965-1966'.

\footnotetext{
${ }^{4}$ J. Śmiałowski, Zakład Taboru..., s. 10-12.

5 Tamże.

${ }^{6}$ K. Woźniak, „Francuską Koleja”” przez Karsznice, „Ziemia Łódzka” 2009, nr 10, s. 20.

7 J. Śmiałowski, Zaktad Taboru..., s. 10-12.

${ }^{8}$ Z. Taylor, Rozwój i regres sieci kolejowej w Polsce, PAN IGiPZ, t. 7, Warszawa 2007, s. 61.

9 Tamże, s. 92-95.
} 


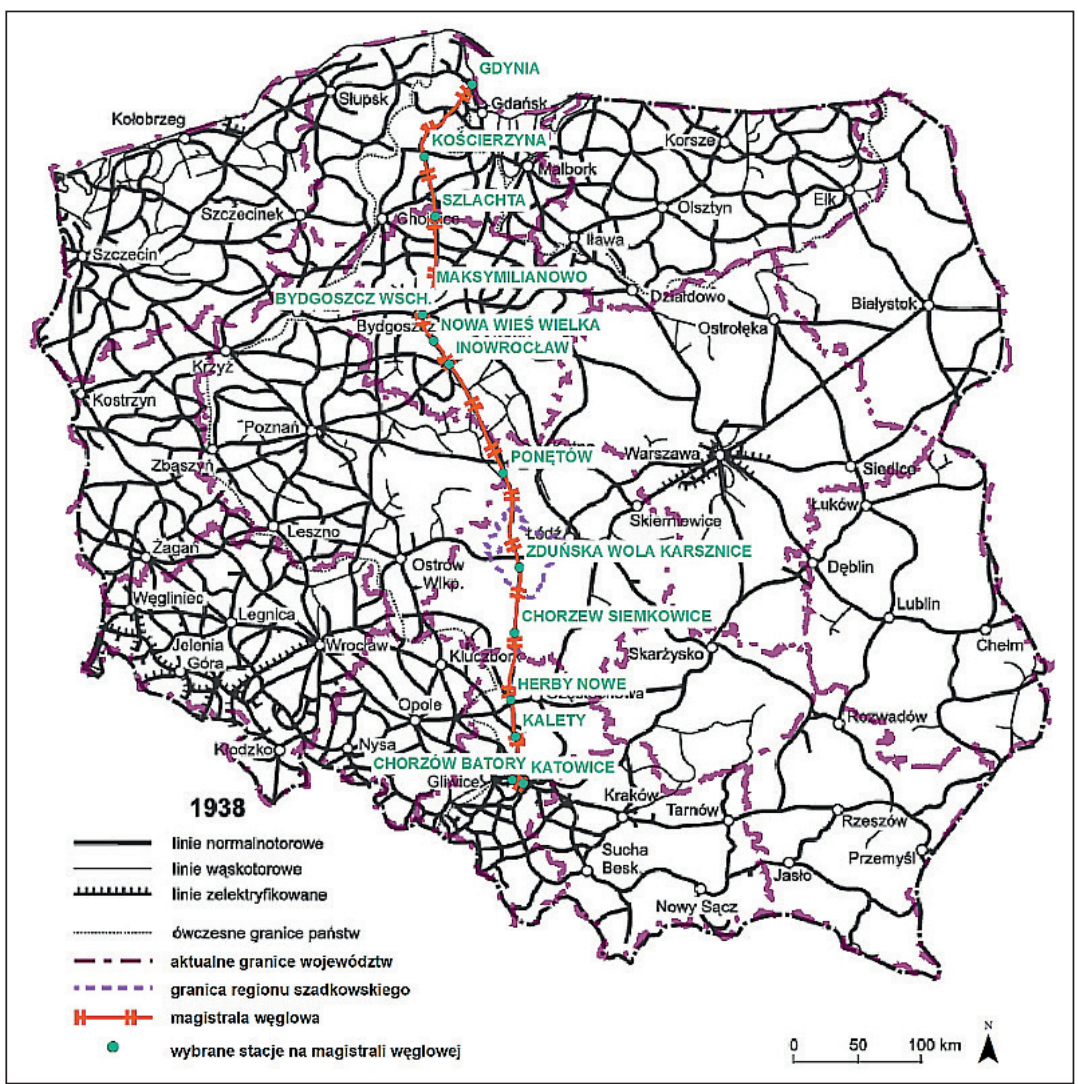

Ryc. 1. Przebieg magistrali węglowej ${ }^{10}$

Źródło: opracowanie własne na podstawie Z. Taylor, Rozwój i regres sieci kolejowej w Polsce, PAN IGiPZ, t. 7, Warszawa 2007, s. 54 oraz http://mapa.plk-sa.pl/ [dostęp 06.02.2016]

\section{MAGISTRALA WĘGLOWA WSPÓŁCZEŚNIE}

Obecnie magistrala węglowa funkcjonuje w ramach odcinków dwóch linii kolejowych: nr 201: Nowa Wieś Wielka - Gdynia Port oraz linii nr 131: Chorzów Batory - Tczew. Linia nr 131 jest linią magistralną, dwutorową, zelektryfikowaną. Linia nr 201 na większości trasy jest linią pierwszorzędną, jednotorową, zelektryfikowaną.

${ }^{10}$ Oznaczenie granic województw ma charakter orientacyjny - mogą występować drobne nieścisłości w zakresie położenia na terenie właściwego województwa elementów zlokalizowanych bezpośrednio przy granicach. 
Magistrala należy do Transeuropejskiej Sieci Transportowej (TEN-T) jako linia C-E 65 , jeden z podstawowych elementów bazowych Korytarza Bałtyk - Adriatyk. Zalicza się do ważnych międzynarodowych linii transportu kombinowanego AGTC ${ }^{11}$.

Przez region szadkowski przebiegają trzy odcinki linii kolejowej nr 131: Chorzew Siemkowice-Zduńska Wola-Karsznice (zwane dalej Z.W. Karsznice), Z.W. Karsznice - Dionizów oraz Dionizów - Ponętów. W granicach regionu na linii zlokalizowanych jest 5 stacji kolejowych (od południa): Kozuby, Z.W. Karsznice, Szadek, Otok i Poddębice. Przed stacją Kozuby znajduje się nieczynny przystanek pasażerski, Siedlce Łaskie, kolejne dwa usytuowane są pomiędzy stacjami Kozuby a Z.W. Karsznice: Kustrzyce oraz Z.W. Karsznice Południowe. Linia nr 131 i krzyżująca się z nią linia nr 14 (Łódź Kaliska - Tuplice) posiadają połączenie dzięki łącznicom i dwóm posterunkom odgałęźnym: Dionizów i Gajewniki. Sąsiednie stacje kolejowe i przystanki pasażerskie lokalizowane są w znacznych odległościach od siebie, na odcinku Siedlce Łaskie - Poddębice przeciętnie co 7,2 km. Największą z nich jest odległość między stacją Otok a Poddębice $-12,1 \mathrm{~km}^{12}$.

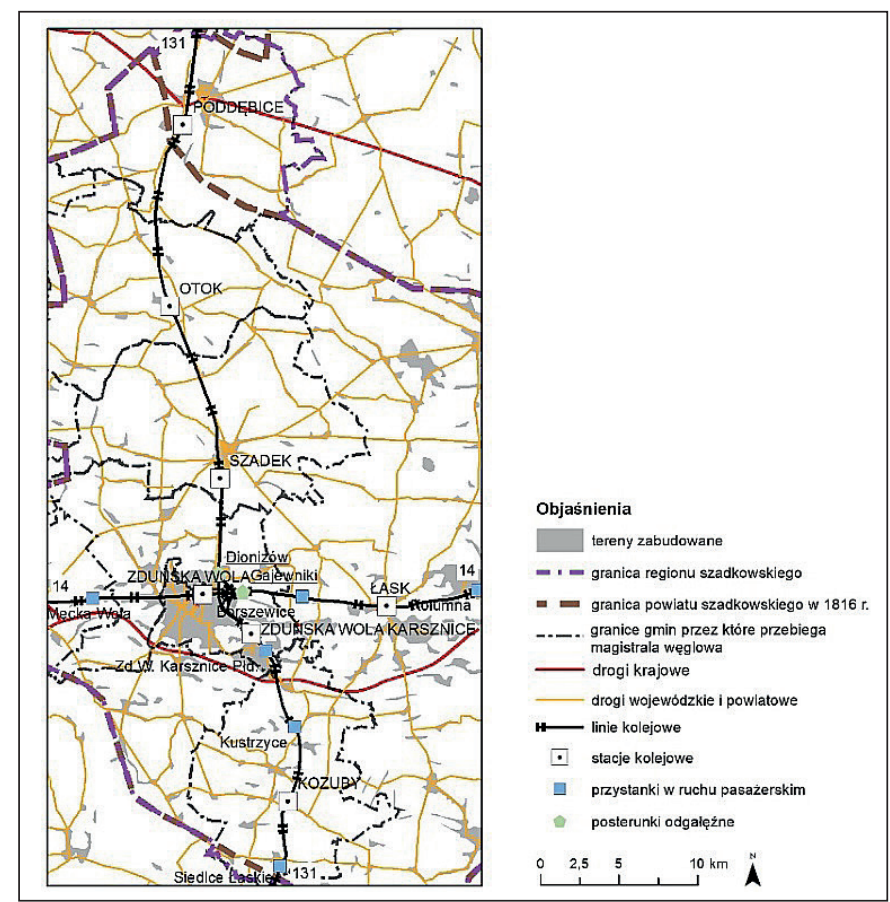

Ryc. 2. Sieć kolejowa w regionie szadkowskim Źródło: opracowanie własne na postawie mapa.plk-sa.pl [dostęp 21.02.2016], baza BDOO oraz T. Marszał, Szadek. Monografia miasta, Szadek 1995, s. 24

${ }^{11}$ Na podstawie mapa.plk-sa.pl [dostęp 21.02.2016].

12 Tamże (odległości na podstawie wartości kilometrażu osi stacji). 


\section{PRZEWOZY}

W początkowym okresie funkcjonowania magistrali, 12 parom pociągów towarowych na dobę towarzyszyła jedna para pociągów osobowych dalekobieżnych Tarnowskie Góry - Gdynia, dwie relacji Katowice - Gdynia, dwa pociągi lokalne z Karsznic do Inowrocławia i do Częstochowy oraz pociąg łącznikowy Zduńska Wola - Z.W. Karsznice. W 1939 r. kursowały dwie pary pociągów osobowych Gdynia - Częstochowa, Gdynia - Katowice oraz 10 par pociągów łącznikowych Zduńska Wola - Z.W. Karsznice. Dzięki rozbudowie stacji i magistrali w okresie okupacji, w tym budowie drugiego toru, przepustowość magistrali wzrosła z 21 par pociągów na dobę do 39 par z Herb Nowych i 43 par w kierunku przeciwnym w 1944 r. W 1950 r. z Karsznic w kierunku południowym jechało siedem par pociągów pasażerskich (w tym trzy do Częstochowy, jeden do Katowic), w kierunku północnym zaś tylko cztery pary, z czego jeden do Gdyni. Między Karsznicami Południowymi a Zduńską Wolą kursowało 16 składów wahadłowych. Ruch towarowy osiągnął apogeum i granicę przepustowości linii w latach 1945-1950, a potem, mimo rozbudowy węzła, w połowie lat 60 . Pasażerom doskwierał okresowy brak ruchu wahadłowego Zduńska Wola - Karsznice Południowe. Na lata 70. przypadł okres największego rozwoju węzła karsznickiego. Przepustowość wzrosła dzięki elektryfikacji linii - w 1973 r. według planu w kierunku Siemkowic wysłano 83 pociągi towarowe, a 81 stamtąd przybywało. W 1976 r. do Karsznic od Chorzewa Siemkowic mogło przybywać 79 stałych i 25 dodatkowych pociągów. Kursy pociągów pasażerskich ograniczone były do kilku par pociągów osobowych i nielicznych, przeważnie sezonowych, pociągów dalekobieżnych. Sytuacja prezentowała się lepiej na niektórych odcinkach, np. Chorzew Siemkowice - Z.W. Karsznice, na którym w 1981 r. kursowało osiem pociągów osobowych oraz pospieszny Kraków - Gdynia. W kierunku Inowrocławia ze stacji Z.W. Karsznice jechało sześć składów osobowych. Dodatkowo 10 par składów wahadłowych zapewniało połączenie ze stacją Zduńska Wola. Wraz ze zmianami ustrojowymi rozpoczął się spadek przewozów na sieci PKP. W 1990 r. w jednym kierunku jechały 64 pociągi stałe i 39 dodatkowych, w drugim 62 stałe i 49 dodatkowych. Do połowy lat 90 . ilość składów w ruchu pasażerskim nie zmieniała się zbytnio. Składy dalekobieżne zaczęto ograniczać po 2000 r. $^{13}$ Ostatecznie na koniec 2008 r. zlikwidowane zostały pociągi osobowe relacji Katowice - Inowrocław, a zastępujące je połączenia o skróconych trasach na koniec 2010 r. Następnie zrezygnowano z sezonowych pociągów ze Śląska nad morze oraz prowadzenia ruchu pasażerskiego ze Zduńskiej Woli do Częstochowy ${ }^{14}$. Obecnie ruch pasażerski na magistrali węglowej w regionie szadkowskim ma charakter sporadyczny,

${ }_{13}$ G. Kotlarz, Zduńska Wola Karsznice, „Świat Kolei” 2011, nr 6, s. 16-25.

${ }^{14} \mathrm{http}: / /$ kurierkolejowy.eu/aktualnosci/10930/magistrala-weglowa-bez-polaczen-pasazerskich. html [dostęp 21.02.2016]. 
ograniczony do pośpiesznych pociągów sezonowych czy np. trzymiesięcznego „eksperymentu” Łódzkiej Kolei Aglomeracyjnej, polegającego na uruchomieniu w 2015 r. lokalnego połączenia Zduńska Wola - Z.W. Karsznice Południowe ${ }^{15}$.

Brak połączeń pasażerskich powoduje, że linia nie wpływa na zwiększenie dostępności transportowej miejscowości w regionie szadkowskim. Na przykład, dla Szadku posiada ona duże znaczenie wyłącznie pod względem dostępności potencjalnej, czyli takiej, która może zaistnieć i wynika z obecności na danym terenie odpowiedniej infrastruktury transportowej w sensie ilościowym i jakościo$\mathrm{wym}^{16}$. Podobnie będzie $\mathrm{w}$ innych miejscowościach położonych wzdłuż magistrali, przy czym poziom dostępności w różnych miejscowościach będzie się różnił ze względu na odmienną ich lokalizację względem stacji i przystanków.

\section{SKUTKI BUDOWY MAGISTRALI KIEDYŚ I DZIŚ}

W regionie szadkowskim budowa magistrali węglowej odegrała największą rolę dla południowo-wschodniej części Zduńskiej Woli. Warunki terenowe zadecydowały o odrzuceniu pomysłu o realizacji węzła poprzez rozbudowę istniejącej stacji na linii Kalisz - Łódź i o budowie nowej stacji towarowej i osobowej w leżącej wówczas poza miastem wsi Karsznice (w 1827 r. liczyła jedynie osiem domów i 106 mieszkańców). Stacja, początkowo IV klasy, służąca głównie jako mijanka, za sprawą rozbudowy w $1930 \mathrm{r}$. zyskała status II klasy, a następnie klasy I ${ }^{17}$. Dla rozwoju Karsznic kluczowe znaczenie miała budowa parowozowni ${ }^{18}$ oddanej do użytkowania w 1933 r. jako pomocniczej III klasy, w 1937 r. przekwalifikowanej na parowozownię główną I klasy. Budowa stacji i parowozowni pociągnęła za sobą potrzebę realizacji kolejnych obiektów kolejowych. Na rozległym terenie w bezpośrednim sąsiedztwie linii powstały m.in.: wagonownia, acetylenownia, stolarnia, budynek straży pożarnej, warsztaty. Rozpoczęcie w 1964 r. eksploatacji lokomotyw spalinowych i elektryfikacja magistrali spowodowały powstanie w 1979 r., w miejscu Oddziału Napraw Rewizyjnych Parowozów, Oddziału Napraw Maszyn Elektrycznych ${ }^{19}$.

Brak tradycji kolejarskich w Karsznicach wymagał przeniesienia pracowników $\mathrm{z}$ innych jednostek. Z myślą o nich w pobliżu parowozowni wybudowano duże osiedle. Przed wybuchem wojny, osiedle liczące 22 bloki, dwa dwurodzinne domki,

15 http://www.transport-publiczny.pl/wiadomosci/lka-likwiduje-miejska-linie-w-zdunskiej-woli-50787.html [dostęp 21.02.2016].

${ }^{16}$ Sz. Wiśniewski, Dostępność transportowa Szadku, „Biuletyn Szadkowski” 2014, t. 14, s. 7.

${ }^{17}$ G. Kotlarz, Zduńska Wola..., s. 16-18, 21.

18 Lokalizacja parowozowni w Karsznicach gwarantowała podobną odległość i do Tarnowskich Gór (144 km) i do Inowrocławia (153 km).

19 J. Śmiałowski, Zakład Taboru..., s. 13, 33-37. 
dwa budynki mieszkalne na stacji oraz 16 domów jednorodzinnych, zamieszkiwało ok. 1300 osób $^{20}$. Po wojnie osiedle rozrastało się dalej - powstało kilkanaście kolejnych bloków, domy dwurodzinne oraz mnóstwo budynków mieszkalnych jednorodzinnych. Powstały obiekty infrastruktury społecznej, jak np. szkoła zawodowa PKP, poczta, stadion, dom kultury czy przychodnia zdrowia ${ }^{21}$.

Osiedle Karsznice i tereny kolejowe zostały włączone do Zduńskiej Woli w 1973 r. Osiedle liczyło wtedy 3090 mieszkańców 22. Według stanu na 2012 r. zamieszkiwało je ok. 4044 osób ${ }^{23}$. Znaczna część zasobu mieszkaniowego została już sprywatyzowana, natomiast gmina przejęła od PKP część zasobów, takich jak np. dom kultury czy stadion ${ }^{24}$.

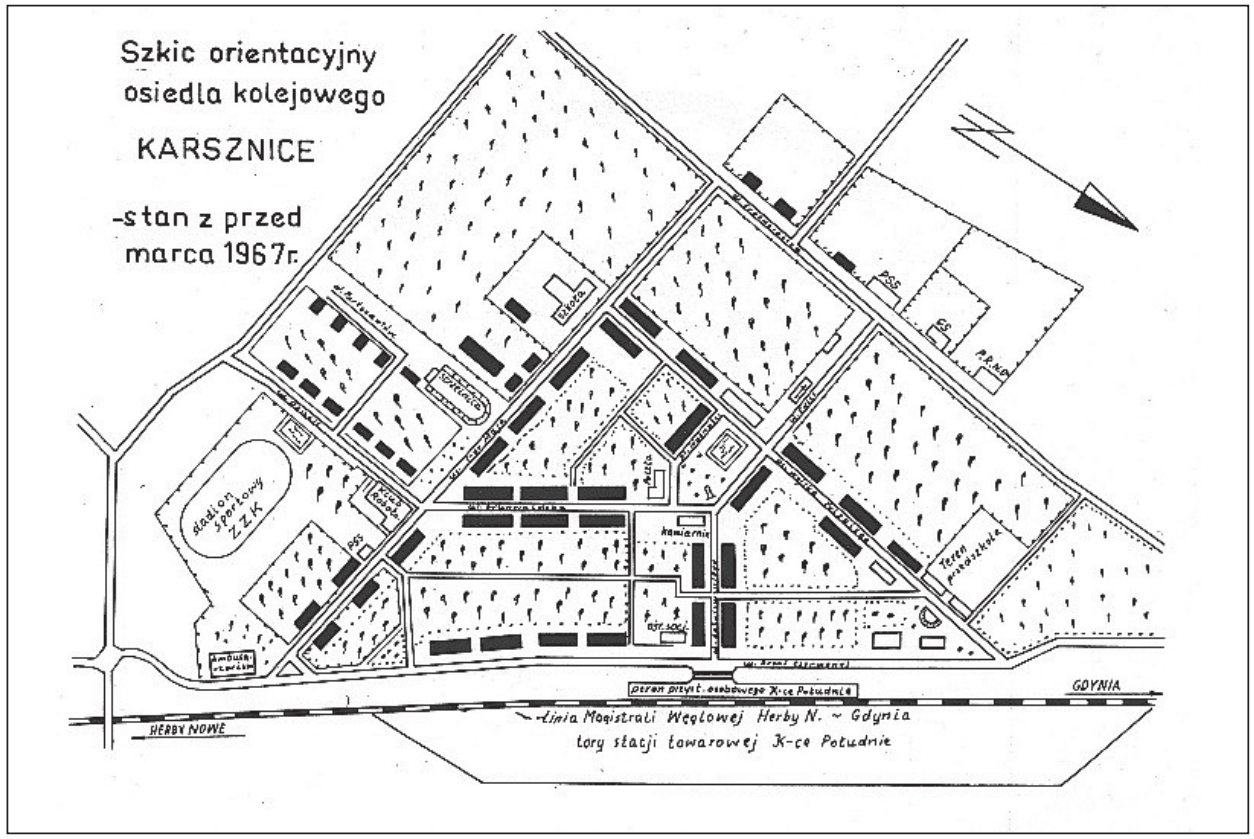

Ryc. 3. Osiedle kolejowe Karsznice przed $1967 \mathrm{r}$.

Źródło: J. Śmiałowski, Zakład Taboru Polskich Kolei Państwowych w Zduńskiej Woli - Karsznicach (1933-1993), ZP POLGRAF, Zduńska Wola 1993

20 Tamże, s. 16-24.

${ }^{21}$ Tamże, s. 23-26, 70-71; G. Kotlarz, Zduńska Wola ..., s. 23.

22 J. Śmiałowski, Zakład Taboru..., s. 70-71.

${ }^{23}$ A. Kącka, Węzet Kolejowy w Karsznicach, [w:] Znaczenie i skutki budowy wybranych elementów infrastruktury nowoczesnego transportu kolejowego, red. R. Kozłowski, Wydawnictwo UŁ, Łódź 2012, s.115.

${ }^{24}$ G. Kotlarz, Zduńska Wola ..., s. 25. 

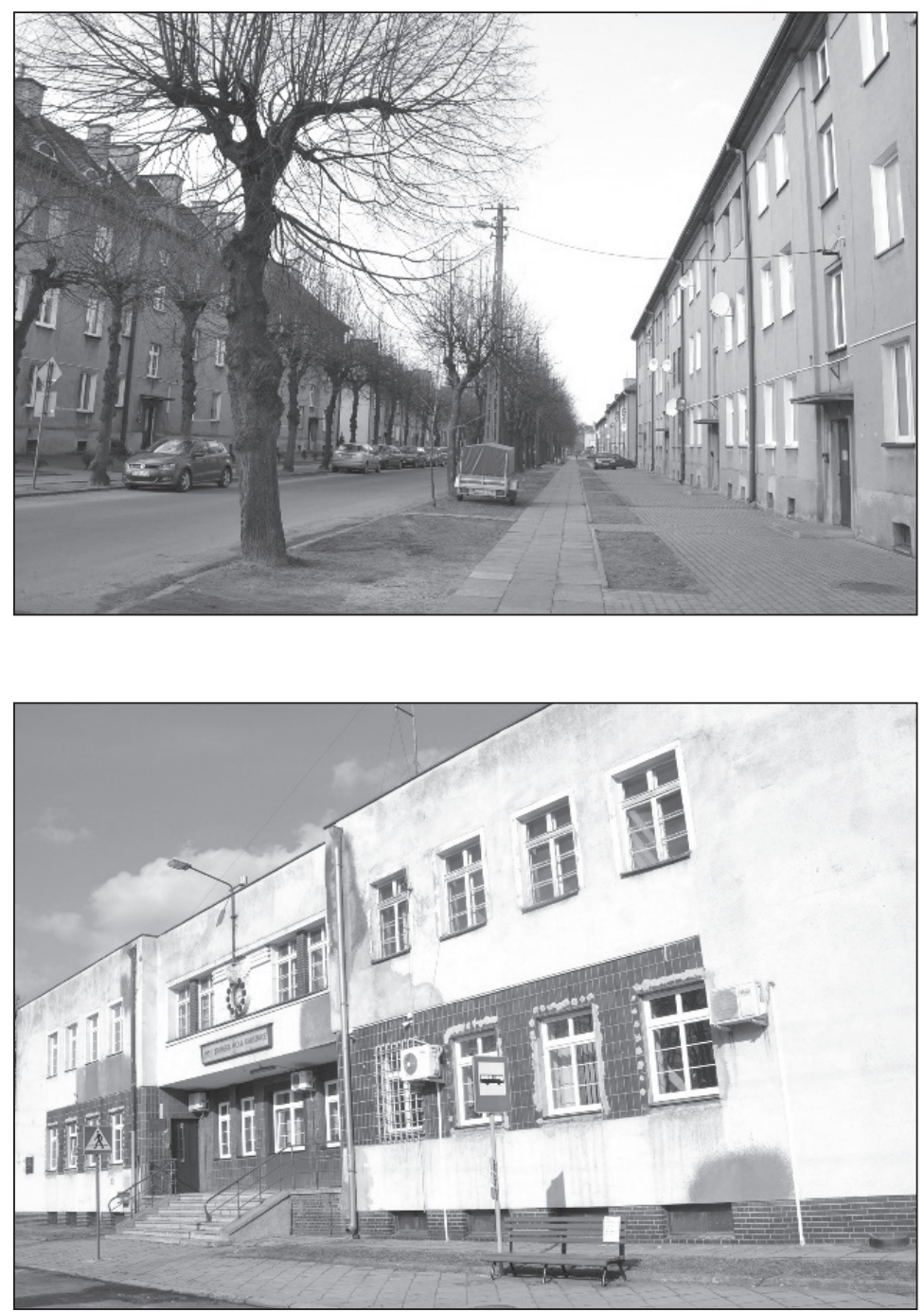

Fot. 1-2. Od góry: Osiedle kolejarskie Karsznice - ul. Grunwaldzka; Stacja Zduńska Wola Karsznice

Źródło: zdjęcia I. Pecyna, 2016

Budowa węzła karsznickiego doprowadziła nie tylko do znacznych przekształceń w zagospodarowaniu przestrzeni, ale także dała nowe miejsca pracy mieszkańcom regionu szadkowskiego, napędzając jego rozwój społeczno-gospodarczy. Zatrudnienie rosło od 90 pracowników parowozowni i 16 stałych pracowników stacji w 1933 r., przez 800 pracowników parowozowni w 1938 r., po szczytowy poziom zatrudnienia w 1978 r., kiedy w całym węźle pracowało 4270 osób, 
w tym 2069 w lokomotywowni i 591 na stacji ${ }^{25}$. Aktualnie Zakład Taboru nie pełni swojej dawnej roli. Na jego terenie w ramach spółki PKP CARGO TABOR funkcjonuje Zakład Napraw Taboru zatrudniający ok. 200 osób. Do jego zadań należy bieżące utrzymanie i naprawa okresowa lokomotyw elektrycznych oraz naprawa podzespołów rezerwy obiegowej (zestawów kołowych) ${ }^{26}$. W budynku dworca siedzibę ma Lotos Kolej Sp. z o.o. - Wydział Przewozów Zduńska Wola.

Ponadto na terenie Zakładu Taboru zlokalizowany jest, otwarty w 1993 r., Skansen Lokomotyw i Urządzeń Technicznych. W Skansenie podziwiać można zabytkowe parowozy oraz inne ,perełki techniki”, a także zwiedzić Izbę Historii Kolei. W 2009 r. teren Skansenu został przejęty przez miasto, a w 2012 r. powołano do życia Stowarzyszenie Miłośników Kolei ${ }^{27}$. W 2015 r. Skansen włączony został w struktury Muzeum Historii Miasta Zduńska Wola ${ }^{28}$.

$\mathrm{Na}$ trasie linii powstały jeszcze cztery małe stacje kolejowe, jednak w ich przypadku budowa magistrali nie wpłynęła tak znacząco na przemiany w zagospodarowaniu przestrzeni. Każda ze stacji jest potwierdzeniem nieuwzględnienia potrzeb społeczności lokalnych i sieci osadniczej podczas trasowania linii. Stacja Kozuby położona jest w miejscowościach Nowe Kozuby oraz Sędziejowice, w gminie Sędziejowice. W jej sąsiedztwie położone są pojedyncze pasma zabudowy zagrodowej oraz teren produkcyjno-składowy. Od najbliższego ośrodka koncentracji zabudowy, tj. miejscowości gminnej, dzieli ją ok. 2,2 km. Otoczona lasem stacja Szadek położona jest w miejscowości Wieś Wielka, w gminie Szadek, ok. 2 km od centrum małego miasta, Szadku. Jednocześnie już w odległości $1,3 \mathrm{~km}$ od stacji zlokalizowane jest gęsto zabudowane osiedle domów jednorodzinnych. Stacja Otok położona w miejscowości Otok, w gminie Zadzim, zlokalizowana jest najbardziej peryferyjnie względem obszarów zabudowanych. W jej sąsiedztwie występuje wyłącznie rozproszona zabudowa zagrodowa. Najbliżej położona miejscowość Zygry, w której koncentruje się (w niewielkim stopniu) zabudowa, oddalona jest o ok. 2,2 km. Stacja Poddębice położona jest w miejscowości Bałdrzychów, w gminie Poddębice. Wzdłuż przebiegającej obok, niemal równoległej do linii kolejowej, drogi skupione jest pasmo zabudowy mieszkaniowej i terenów przemysłowo-magazynowo-składowych. Stację dzieli ok. 2,3 km od centrum miasta - Poddębic.

Każda ze stacji posiada po dwa perony, cztery tory główne, kilka torów bocznych. Wyjątkiem jest stacja Kozuby posiadająca aż siedem torów głównych ${ }^{29}$, gdyż w szczytowych okresach przewozów pełniła ona względem stacji Z.W. Kar-

${ }^{25}$ G. Kotlarz, Lokomotywownia Karsznice, „Świat Kolei” 2008, nr 10, s. 15-20; J. Śmiałowski, Zaktad Taboru..., s. 18-31, 52-53.

${ }^{26} \mathrm{http}: / /$ www.cargowag.pl/o-firmie/mapa.html\# [dostęp 13.02.2016].

$27 \mathrm{http} / / / w w w . s k a n s e n . z d u n i a . p l /$ [dostęp 27.01.2016].

${ }^{28} \mathrm{http}: / /$ muzeumzdunskawola.blogspot.com/p/skansen-lokomotyw-karsznice.html [dostęp 13.02.2016].

${ }^{29} \mathrm{http} / / /$ semaforek.kolej.org.pl [dostęp 13.02.2016]. 
sznice rolę pomocniczego punktu rewidenckiego ${ }^{30}$. Budynki stacyjne oraz plac ładunkowy na stacjach Kozuby (oprócz dwóch obiektów) i Otok zlokalizowane są po zachodniej stronie stacji, zaś na stacjach Szadek i Poddębice po stronie wschodniej. Dwupiętrowe dworce przystosowane były do obsługi ruchu towarowego i pasażerskiego - według projektu mieściły się w nich: gabinet zawiadowcy stacji, pomieszczenia mieszczące stawidła i telegraf, pomieszczenie bagażowe, hala, kasa, poczekalnia oraz dwa mieszkania dla pracowników (ryc. 4). Wymienione stacje $\mathrm{w}$ znikomym zakresie pełnią swoje pierwotne funkcje. W ramach organizacji ruchu kolejowego na stacjach funkcjonują wyłącznie po dwie nastawnie - jedna w parterze każdego dworca oraz jedna wolno stojąca w drugim końcu stacji. Dworce na stacji Szadek i Poddębice, poza wykorzystaniem niewielkiej powierzchni na potrzeby nastawni, nie są użytkowane. Od końca 2014 r. PKP oferuje, bez skutku, wynajęcie lokalu użytkowego w szadkowskim dworcu ${ }^{31}$. Poza nastawniami, na stacji Kozuby, w części dworca na parterze oraz na 1-szym piętrze swoją siedzibę zlokalizowała hurtownia hydrauliczno-budowlana, natomiast na stacji Otok, w dworcu usytuowane są także mieszkania. Jednocześnie część pomieszczeń w tych dwóch dworcach nie jest użytkowana.

Dworcom na stacjach towarzyszą inne obiekty ${ }^{32}$ :

- na stacji Kozuby: dawny magazyn olejów (wykorzystywany jako budynek gospodarczo-garażowy), szalet (przebudowany, nieużytkowany) oraz dawne schronisko (wykorzystywane z otaczającym je placem na potrzeby składowo-magazynowe), budynki gospodarcze oraz w oddaleniu od tych obiektów, budynek mieszkalny jednorodzinny i budynek gospodarczy.

- na stacji Szadek: zamieszkały budynek mieszkalny wielorodzinny wraz z towarzyszącą mu zabudową gospodarczą, nieużytkowany budynek toalet, magazyn przesyłek; plac ładunkowy został wynajęty i użytkowany jest jako skład węgla.

- na stacji Otok: trzy budynki mieszkalne wraz z towarzyszącą im zabudową gospodarczą oraz budynek warsztatowo-magazynowy postawiony w stan likwidacji wraz z jednym z budynków mieszkalnych i jednym z gospodarczych.

- na stacji Poddębice: trzy zamieszkałe budynki mieszkalne, budynki gospodarcze, budynek toalet, magazyn przesyłek i garaż.

Budynki stacyjne w większości są w średnim stanie technicznym. Nieużytkowane powierzchnie ze względu na stan techniczny, lokalizację stacji w oddali od lokalnych ośrodków koncentracji zabudowy oraz sąsiedztwo czynnej linii kolejowej, generującej uciążliwości (np. hałas, drgania), mają niski potencjał komercyjny czy też szanse na wykorzystanie na cele mieszkaniowe. Obszary stacji ewentualnie mogą być atrakcyjnym miejscem do lokalizacji działalności

${ }^{30}$ G. Kotlarz, Zduńska Wola..., s. 23-24.

31 http://pkpsa.pl/nieruchomosci/wynajem/nieruchomosc.html?id=6747 [dostęp 13.03.2016].

${ }^{32} \mathrm{Na}$ podstawie inwentaryzacji w terenie oraz danych udostępnionych przez PKP S.A. w zakresie posiadanego mienia oraz obiektów przewidzianych do likwidacji (2015). 
związanej ze składowaniem produktów i ich sprzedażą, jak ma to miejsce w Szadku lub Kozubach (dla tego rodzaju działalności brak sąsiedztwa terenów mieszkaniowych, duże powierzchnie czy też możliwość wykorzystania wybranych torów stacyjnych mogą być zaletą).

Problemem stacji jest także brak docenienia ich walorów zabytkowych ${ }^{33}$ i kulturowych. Podczas budowy magistrali przewidziano realizację na jej długości 33 małych stacji, z „typowym”, niewielkim budynkiem dworca. Ze względu na specyfikę linii, nie brano pod uwagę wykorzystania projektów już istniejących (ówczesne nowe linie nie przewidywały jednoczesnego ruchu tranzytowego, lokalnego towarowego i pasażerskiego; dworce posiadające indywidualne projekty nie spełniały podstawowego kryterium oszczędności; nie miały pomieszczenia na aparaty stawidłowe związanego z budynkiem i z dobrą widzialnością). Na początku 1928 r. w Zarządzie Budowy ustalono wymagania, którym powinien sprostać budynek typowego dworca, jak np. $W d$ worcu winny być 2 mieszkania: 3-pokojowe o pow. $75 \mathrm{~m}^{2}$ i 2-pokojowe o pow. $60 \mathrm{~m}^{2}$, Stawidło musi być wsunięte przynajmniej na 2,0 m poza budynek [...]. Ze stawidła musi być bezpośrednie wyjście na peron. Pierwszy projekt dworca, nazwany typem „Bydgoszcz - Gdynia” powstał za sprawą architekta Tatarczucha. Na jego podstawie wybudowano 11 małych dworców na północnym odcinku magistrali. Z powodu pewnych zarzutów względem tego projektu, w 1930 r. ogłoszono konkurs na projekt uwzględniający szereg dodatkowych wymogów. Zwycięski projekt, Typ I „Herby - Inowrocław" autorstwa T. Kosickiego i B. Nowaka, ze względu na brak możliwości przebudowy dworca w przyszłości, nadawał się wyłącznie do realizacji dworców, których rozwoju nie przewidywano. Zarząd Budowy, dysponując szeregiem prac konkursowych, podjął się wykonania kolejnego projektu, który uwzględniałby możliwość rozwoju stacji. Na początku 1930 r., za sprawą technika A. Kozaka, powstał projekt „Typ II Herby - Inowrocław”, według którego zrealizowano m.in. dworce na stacjach w regionie szadkowskim ${ }^{34}$.

Walory architektoniczne i kulturowe małych stacji zagrożone są przede wszystkim przez niewielki stopień wykorzystania budynków stacyjnych oraz ich pogarszający się stan techniczny. Paradoksalnie, zagrożeniem mogą być remonty i modernizacje, jak np. w przypadku stacji Kozuby. Remont części elewacji dworca i wymiana stolarki okiennej i drzwiowej podniosły walory użytkowe i estetyczne budynku, ale wymiana okien na nieposiadające tradycyjnego podziału, częściowo pozbawiła obiekt zabytkowego charakteru (por. fot. 3-10).

${ }^{33}$ Każda z 4 stacji, jako „Zespół dworca PKP”, uzyskała wpis do Wojewódzkiej Ewidencji Zabytków.

${ }^{34}$ K.S. Brandt, Dworce na małych stacjach Ślask - Gdynia, „, Inżynier Kolejowy” 1931, nr 7, s. 209-213. 

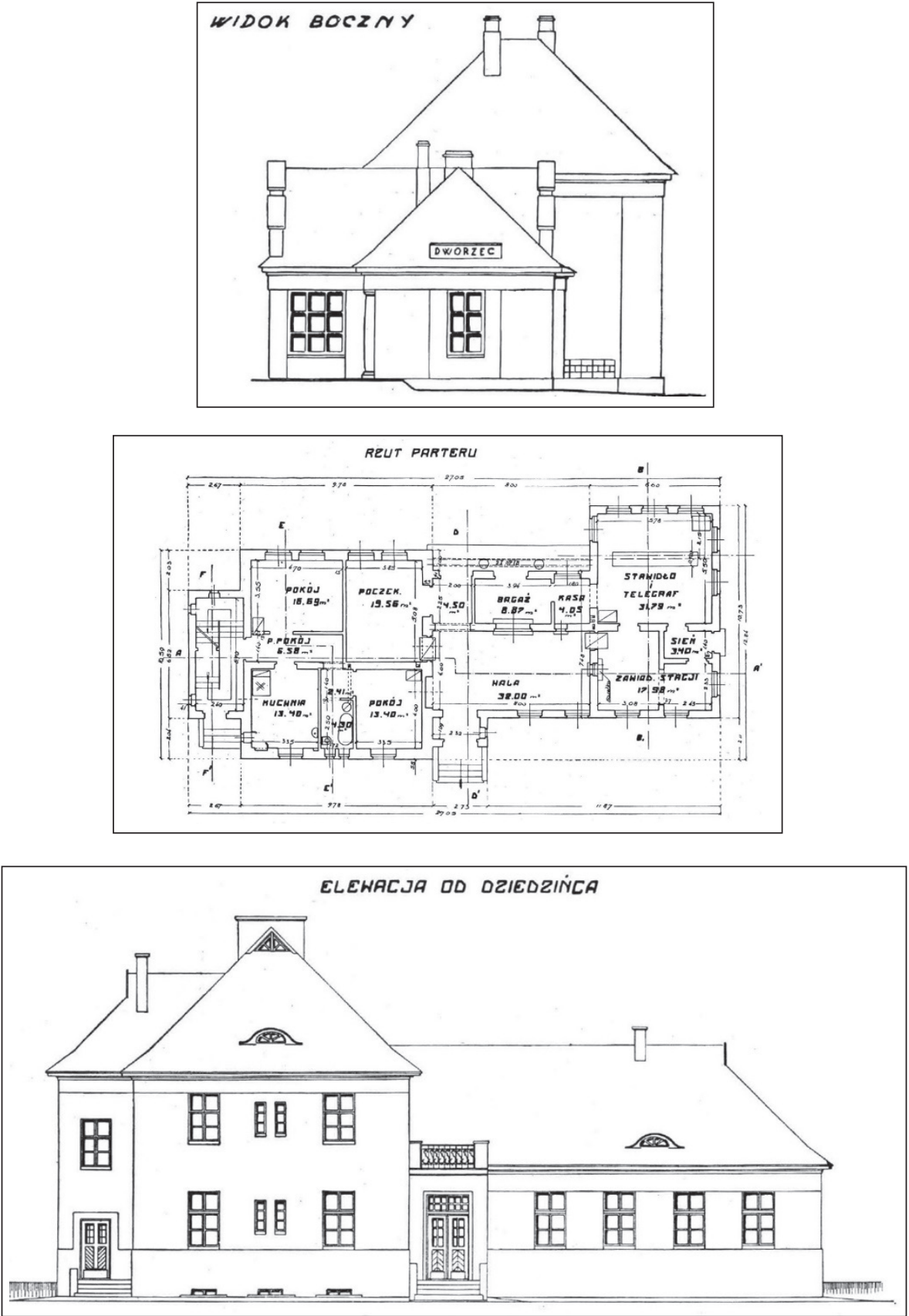

Ryc. 4. Projekt budynku dworca: typ II Herby - Inowrocław Źródło: K.S. Brandt, Dworce na małych stacjach Śląsk - Gdynia, „Inżynier Kolejowy” 1931, nr 7, s. 213 

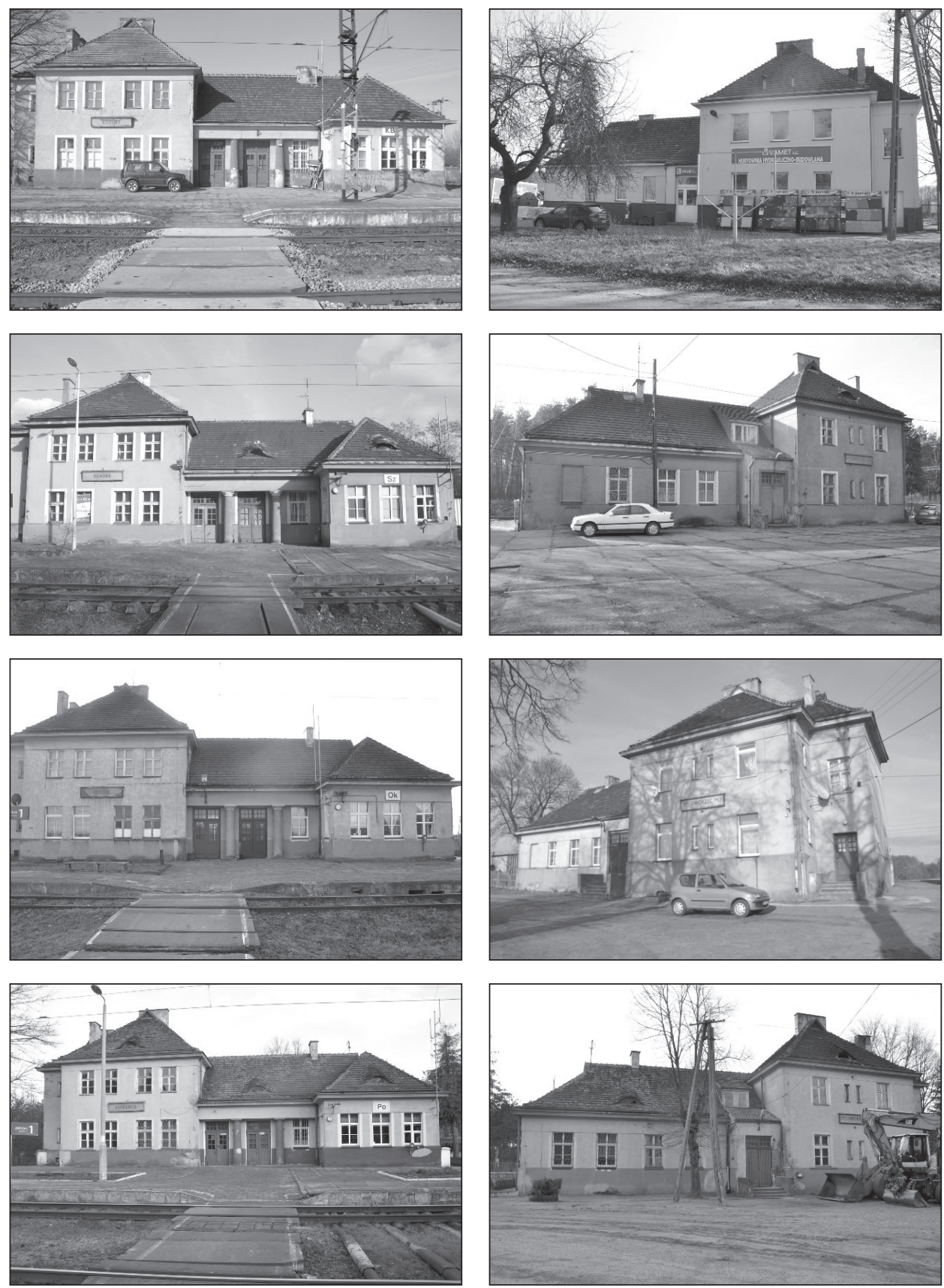

Fot. 3-10. Dworce na małych stacjach - ujecia od torów (po lewej stronie) i z placu przydworcowego (po prawej stronie). Stacje (od góry, każda stacja po dwa zdjęcia - od torów i od placu): Kozuby, Szadek, Otok, Poddębice

Źródło: zdjęcia I. Pecyna, 2016 


\section{LINIA KOLEJOWA JAKO BARIERA PRZESTRZENNA}

Linie kolejowe są barierami przestrzennymi m.in. w sensie komunikacyjnym - nie w każdym miejscu można przedostać się na drugą ich stronę. Pojmowanie linii nr 131 jako bariery przestrzennej w regionie szadkowskim związane jest przede wszystkim z prowadzeniem niektórych jej odcinków na nasypach. Przejazdy pod linią przecinające nasyp nie są dostosowane do współczesnych potrzeb i większość z nich posiada ograniczenie wysokości przejeżdżającego pojazdu do 3,0-3,5 m (pojazdy o wysokości tylko do 3,5 m przejadą m.in. zmodernizowanym przejazdem w drodze wojewódzkiej nr 481). W przypadku przejazdu łączącego Janiszewice i Maciejów (obok Zduńskiej Woli) ograniczenie wynosi aż 2,5 m. Powyższe oznacza brak możliwości przejazdu i konieczność nadkładania drogi przez wyższe pojazdy, np. autobusy, wozy strażackie czy, co szczególnie istotnie w obszarze wykorzystywanym rolniczo, maszyny rolnicze.

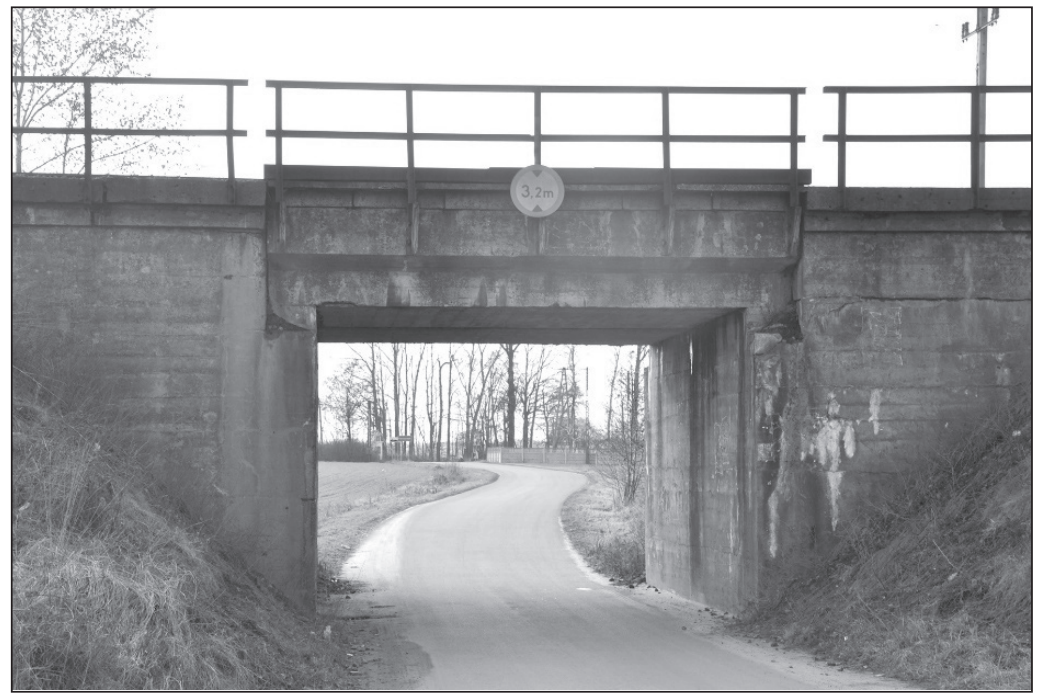

Fot. 11. Przejazd pod linią kolejową między miejscowościami Dziewulin a Karczówek w gminie Szadek - ograniczenie wysokości pojazdów do 3,2 m Źródło: zdjęcie I. Pecyna, 2016

\section{PODSUMOWANIE}

Budowa magistrali węglowej w przeszłości odegrała bardzo duże znaczenie dla rozwoju i przekształcenia przestrzeni regionu szadkowskiego, a w szczególności dla dzielnicy Karsznice w Zduńskiej Woli. Zakłady kolejowe oraz stacje 
dawały zatrudnienie licznym mieszkańcom całego regionu. Linia poprawiała dostępność transportową mimo ograniczonego ruchu pasażerskiego. Wraz z okresem transformacji i spadkiem przewozów, linia przestała być dla regionu czynnikiem rozwoju. Drastycznie zmalała liczba osób zatrudnionych w obsłudze stacji oraz karsznickich zakładach, część obiektów stała się zbędna i zaczęła niszczeć. Uwidocznił się problem trasowania linii z pominięciem potrzeb społecznych i oddalenia stacji od obszarów koncentracji zabudowy, m.in. przez co transport pasażerski nie mógł konkurować z coraz popularniejszym transportem indywidualnym, doprowadzając do jego likwidacji i pogarszając dostępność transportową do miejscowości położonych w regionie. Z czasów świetności pozostało głównie dziedzictwo kulturowe - układ urbanistyczny osiedla Karsznice, wartościowe obiekty architektoniczne, w szczególności w postaci obiektów stacyjnych, oraz zabytki techniki.

Mimo „upadku” znaczenia magistrali węglowej, ona sama oraz lokalizacja Karsznickiego Węzła Kolejowego w regionie szadkowskim odgrywają bardzo ważną rolę dla jego perspektywicznego rozwoju. Zaliczenie linii kolejowej nr 131 do sieci TEN-T, przebieg magistrali i istnienie karsznickiej infrastruktury, w połączeniu z przebiegiem drogi krajowej nr 12, drogi ekspresowej S8 (w sąsiedztwie terenów kolejowych) oraz linii kolejowej nr 14, stały się podstawą do wyznaczenia Miejskiego Obszaru Funkcjonalnego (MOF) o charakterze transportowo-przemystowym na terenie Powiatu Zduńskowolskiego i Powiatu Łaskiego wokót węzła drogi ekspresowej S8 Zduńska Wola Karsznice oraz magistrali kolejowej Ślask - Porty. W ramach MOF planowana jest budowa multimodalnego węzła transportowego oraz powstanie nowych terenów inwestycyjnych o charakterze przemysłowym, transportowo-spedycyjnym, a także usługowym ${ }^{35}$. Istnieje więc szansa, że magistrala ponownie pozytywnie wpłynie na rozwój społeczno-gospodarczy w regionie szadkowskim.

\section{Bibliografia}

Brandt K.S., Dworce na matych stacjach Śląsk - Gdynia, „Inżynier Kolejowy” 1931, nr 7, s. 209-213.

Kącka A., Węzet Kolejowy w Karsznicach, [w:] Znaczenie i skutki budowy wybranych elementów infrastruktury nowoczesnego transportu kolejowego, red. R. Kozłowski, Wydawnictwo UŁ, Łódź 2012, s. 111-125.

Kotlarz G., Lokomotywownia Karsznice, „Świat Kolei” 2008, nr 10, s. 14-21.

Kotlarz G., Zduńska Wola Karsznice, „Świat Kolei” 2011, nr 6, s. 16-25.

Marszał T., Szadek. Monografia miasta, Szadek 1995.

${ }^{35}$ Plan rozwoju Miejskiego Obszaru Funkcjonalnego Zduńska Wola-Karsznice na lata 20142020 (projekt, 2014 r.). 
Michalski P., Czarna magistrala, „Świat Kolei” 2002, nr 2, 10-12.

Plan rozwoju Miejskiego Obszaru Funkcjonalnego Zduńska Wola - Karsznice na lata 2014-2020 (projekt, 2014 r.).

Śmiałowski J., Zakład Taboru Polskich Kolei Państwowych w Zduńskiej Woli - Karsznicach (1933-1993), ZP POLGRAF, Zduńska Wola 1993.

Taylor Z., Rozwój i regres sieci kolejowej w Polsce, PAN IGiPZ, t. 7, Warszawa 2007.

Wiśniewski Sz., Dostępność transportowa Szadku, „Biuletyn Szadkowski” 2014, t. 14, s. 5-23.

Woźniak K., ,Francuska Koleja” przez Karsznice, „Ziemia Łódzka” 2009, nr 10, s. 20.

Wykaz obiektów wpisanych do Wojewódzkiej Ewidencji Zabytków, http://www.wuoz. bip.lodz.pl/page/ 12,zabytki.html [dostęp 13.02.2016]

\section{Strony internetowe}

http://www.cargowag.pl/o-firmie/mapa.html\# [dostęp 13.02.2016].

http://kurierkolejowy.eu/aktualnosci/10930/magistrala-weglowa-bez-polaczen-pasazer-

skich.html [dostęp 21.02.2016].

http://mapa.plk-sa.pl/ [dostęp 21.02.2016].

http://muzeumzdunskawola.blogspot.com/p/skansen-lokomotyw-karsznice.html [dostęp

13.02.2016].

http://pkpsa.pl/nieruchomosci/wynajem/nieruchomosc.html?id=6747 [dostęp 13.03.2016]. http://semaforek.kolej.org.pl [dostęp 13.02.2016].

http://www.skansen.zdunia.pl/ [dostęp 27.01.2016].

http://www.transport-publiczny.pl/wiadomosci/lka-likwiduje-miejska-linie-w-zdunskiej-

-woli-50787.html [dostęp 21.02.2016].

[Wpłynęło: marzec; poprawiono: czerwiec 2016 r.]

\section{THE POLISH COAL TRUNK-LINE IN THE REGION OF SZADEK}

\section{Summary}

Construction of the Polish Coal Trunk-Line was one of the largest Polish investments of the interwar period. It connected Upper Silesia with the Baltic Sea, with the newly built port of Gdynia, providing new opportunities for the export of Polish coal. Since then, the railway line remains one of the most important in the country. It was primarily designed for freight transport, but it served also some passenger connections. The Coal Trunk-Line crosses the central part of the country, including Szadek municipality and its surroundings. The article describes the changes that the construction of the railway line brought for the region of Szadek, and points out its present importance for the town.

Keywords: Polish Coal Trunk-Line, the region of Szadek, small railway stations, the railwaymen housing estate. 